HortSCIENCE 25(10):1219-1221. 1990.

\section{Rootstock and Site Influence Performance of 'McIntosh' Apple Trees}

\author{
Wesley R. Autio, William J. Lord, and Peter L.M. Veneman \\ Department of Plant and Soil Sciences, University of Massachusetts, \\ Amherst, MA 01003
}

Additional index words. Malus domestics, soil moisture, productivity, yield efficiency,
nonirrigated

Abstract. 'Marshall McIntosh' apple trees (Malus domestics Borkh.) on M.7A, M.26, M.9/MM.106, and M.9/MM.111 were planted at 10 locations in Massachusetts. After seven growing seasons, trees on M.7A were the largest and trees on M.26, M.9/MM.106, and M.9/MM.111 were similar in size on all sites. Trees on M.7A outyielded (198688) trees on the other rootstock at only three of the 10 sites. At three sites, trees on M.7A and, M.26 were similarly yield-efficient, but on all other sites trees on M.7A were the least efficient. Trees on M.9/MM.111 and M.9/MM.106 were similarly efllcient on all but two sites.

Apple trees on a given rootstock often perform differently on different orchard sites. Likely, the predominant site factors governing these differences in performance are soil characteristics. Studies have evaluated differences in rootstock adaptability under controlled stress conditions, such as flooding (Rem and Brown, 1979), anoxia (Makariev, 1977), drought (Carlson, 1967), and Phytophthora infection (Harris and Pearse, 1938). While these studies provide valid information, research must ultimately be done on tree development and productivity in the field to confirm relationships under' natural conditions. Thus, we initiated a study comparing the growth and productivity of four apple rootstock grown under controlled management conditions at 10 locations with various soil conditions.

Ten sites were selected throughout Massachusetts. The soils at each site were checked for homogeneity using auger borings. At a representative location within each site, a 1 $\times 1 \times 1 \mathrm{~m}$ pit was excavated. A soil description was prepared using standard terminology (Soil Survey Staff, 1972), and the major horizons were sampled for laboratory analysis.

'Marshall McIntosh' trees on M.7A, M.26, M.9/MM.106, and M.9/MM.111 were planted at the 10 locations in late Apr. to May 1982. Each location included eight replications of the four rootstock combinations in a randomized complete-block design, with single trees serving as experimental units. The overall experimental design was a split

Received for publication 1 Dec. 1989. Massachusetts Agricultural Experiment Station Paper 2922. The cost of publishing this paper was defrayed in part by the payment of page charges. Under postal regulations, this paper therefore must be hereby marked advertisement solely to indicate this fact.
$\mathrm{N} /$ tree 2 weeks after planting; $125 \mathrm{~g} \mathrm{~N} /$ tree Apr. 1983; 200 g N/tree Apr. 1984; 275 g $\mathrm{N} /$ tree Apr. 1985-88). Boron was applied in 1986 (10 g/tree). Nutrient deficiencies were corrected as necessary. Weed-free strips (2 $\mathrm{m})$ were maintained in the tree row using paraquat during the first season, paraquat plus simazine the second and third seasons, glyphosate plus simazine the fourth, fifth, and sixth seasons, and glyphosphate the seventh season. Spot treatments of appropriate herbicides were used when necessary to control problem weeds. All trees were trained to central leaders with minimal dormant pruning. Trees were staked only when they leaned more than $20^{\circ}$ from vertical.

Tree height, spread, and trunk circumference $(50 \mathrm{~cm}$ above soil surface) were measured each year in October. Circumference data were transformed to cross-sectional areas. Trees were not allowed to fruit until 1986; in 1986 and in subsequent years total yield from each tree was measured.

Since some trees died, the Mixed Model Least-squares and Maximum Likelihood computer program (Harvey, 1985) was used for statistical analyses. This program uses least-squares analysis of data to account for missing observations (Harvey, 1979). Where significant interactions existed between the effects' of site and rootstock, the total sums of squares for rootstock and for the interaction were repartitioned into units representing the differences among rootstock ization in the form of $10 \mathrm{~N}-20 \mathrm{P}-20 \mathrm{~K}(50 \mathrm{~g}$

plot with locations as whole plots. Thereore, replications were nested' within location. A single 'Red Chief Delicious'/M.7A Trees were planted with the bud union (or the top union of the interstem trees) $5 \mathrm{~cm}$ above the soil surface and were spaced 4.3

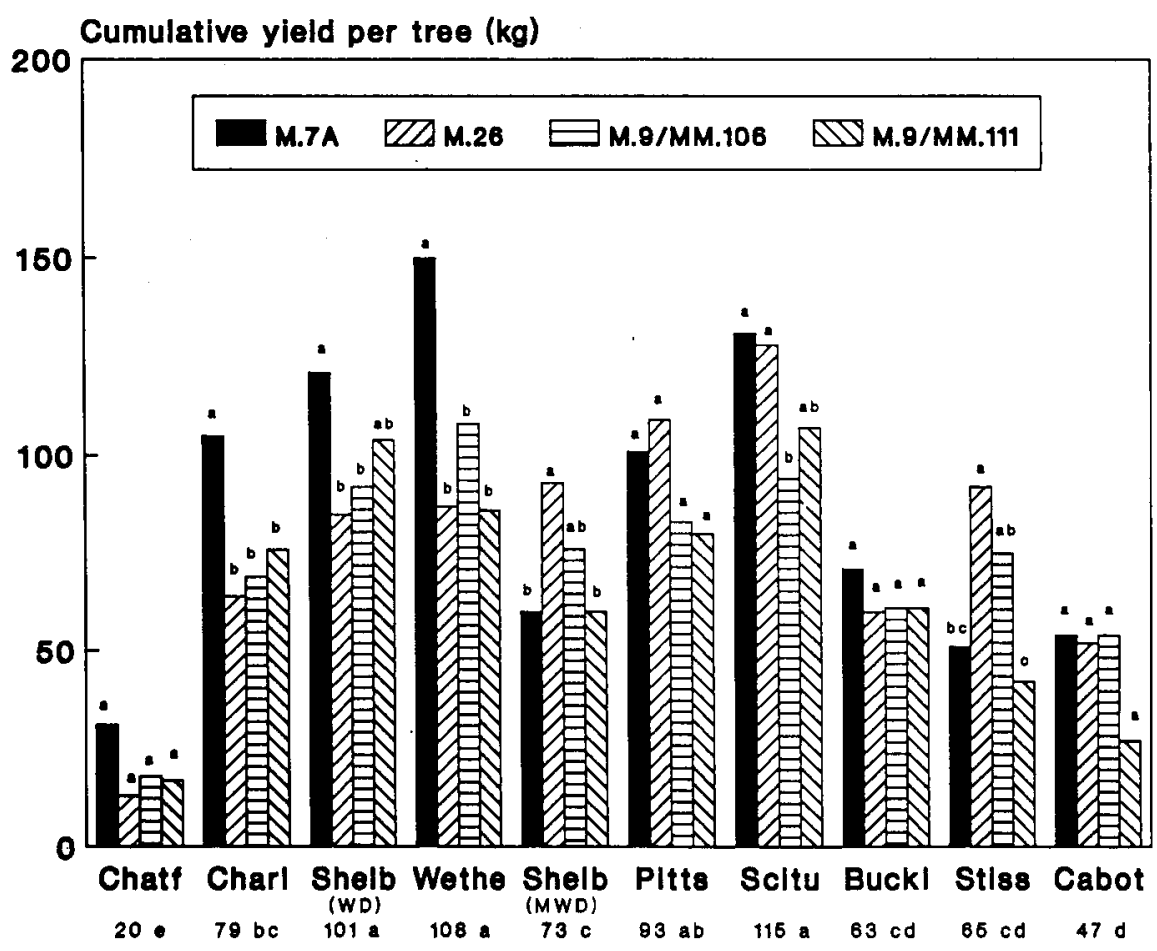

Fig. 1. Cumulative yields per tree (1986-88) of 'Marshall McIntosh' on M.7A, M.26, M.9/MM.106, and M.9/MM.111 planted in 1982. Each bar represents the mean of eight observations, except where trees died. Within location, mean separation was by Duncan's new multiple range test, $P=0.05$. Location means (means of 32 observations, except where trees died) appear below the $\mathrm{x}$ axis labels and are separated by Duncan's new multiple range test, $P=0.05$. WD $=$ well-drained soil; MWD $=$ moderately well-drained soil. 
Table 1. Soil characteristics at the 10 locations used in this study. Drainage class abbreviations: SED = somewhat excessively drained; WD = well-drained; MWD = moderately well-drained; SPD = somewhat poorly drained; PD = poorly drained.

\begin{tabular}{|c|c|c|c|c|c|c|}
\hline $\begin{array}{l}\text { Soil } \\
\text { series }\end{array}$ & $\begin{array}{l}\text { Soil classification/ } \\
\text { particle size class }\end{array}$ & $\begin{array}{l}\text { Soil texture } \\
(0-30 \mathrm{~cm})\end{array}$ & $\begin{array}{l}\text { Depth of } \\
\text { A horizon } \\
(\mathrm{cm})\end{array}$ & $\begin{array}{l}\text { Depth to } \\
\text { hard pan } \\
(\mathrm{cm})\end{array}$ & $\begin{array}{l}\text { Depth to seasonal } \\
\text { high water } \\
\text { table }(\mathrm{cm})\end{array}$ & $\begin{array}{l}\text { Drainage } \\
\text { class }\end{array}$ \\
\hline Chatfield $^{2}$ & $\begin{array}{l}\text { Typic Dystrochrept } \\
\text { coarse-loamy, mixed, mesic }\end{array}$ & Fine sandy loam & 21 & $66^{y}$ & $>66$ & SED \\
\hline Charlton & $\begin{array}{l}\text { Typic Dystrochrept } \\
\text { coarse-loamy, mixed, mesic }\end{array}$ & Fine sandy loam & 18 & $>90$ & $>105$ & WD \\
\hline Shelburne & $\begin{array}{l}\text { Typic Dystrochrept } \\
\text { coarse-loamy, mixed, mesic }\end{array}$ & Fine sandy loam & 15 & 52 & $>77$ & WD \\
\hline Wethersfield & $\begin{array}{l}\text { Typic Dystrochrept } \\
\text { coarse-loamy, mixed, mesic }\end{array}$ & Fine sandy loam & 18 & 89 & $>105$ & WD \\
\hline Shelburne & $\begin{array}{l}\text { Typic Dystrochrept } \\
\text { coarse-loamy, mixed, mesic }\end{array}$ & Fine sandy loam & 18 & 69 & $>86$ & MWD \\
\hline Pittstown & $\begin{array}{l}\text { Typic Dystrochrept } \\
\text { coarse-loamy, mixed, mesic }\end{array}$ & Silt loam & 15 & 52 & 52 & MWD \\
\hline Scituate & $\begin{array}{l}\text { Typic Dystrochrept } \\
\text { coarse-loamy, mixed, mesic }\end{array}$ & Fine sandy loam & 23 & 61 & 50 & MWD \\
\hline Buckland & $\begin{array}{l}\text { Typic Dystrochrept } \\
\text { coarse-loamy, mixed, mesic }\end{array}$ & Fine sandy loam & 10 & 39 & 39 & SPD \\
\hline Stissing & $\begin{array}{l}\text { Aeric Haplaquept } \\
\text { coarse-loamy, mixed, mesic }\end{array}$ & Silt loam & 33 & 53 & 46 & SPD \\
\hline Cabot & $\begin{array}{l}\text { Typic Haplaquept } \\
\text { coarse-loamy, mixed, non-acid } \\
\text { mesic }\end{array}$ & Fine sandy loam & 13 & 46 & 26 & PD \\
\hline
\end{tabular}

${ }^{2}$ This soil is a variant, since coarse sand starts at $49 \mathrm{~cm}$.

Depth to ledge.

\section{Cumulative yield efficiency $\left(\mathrm{kg} / \mathrm{cm}^{2}\right)$}

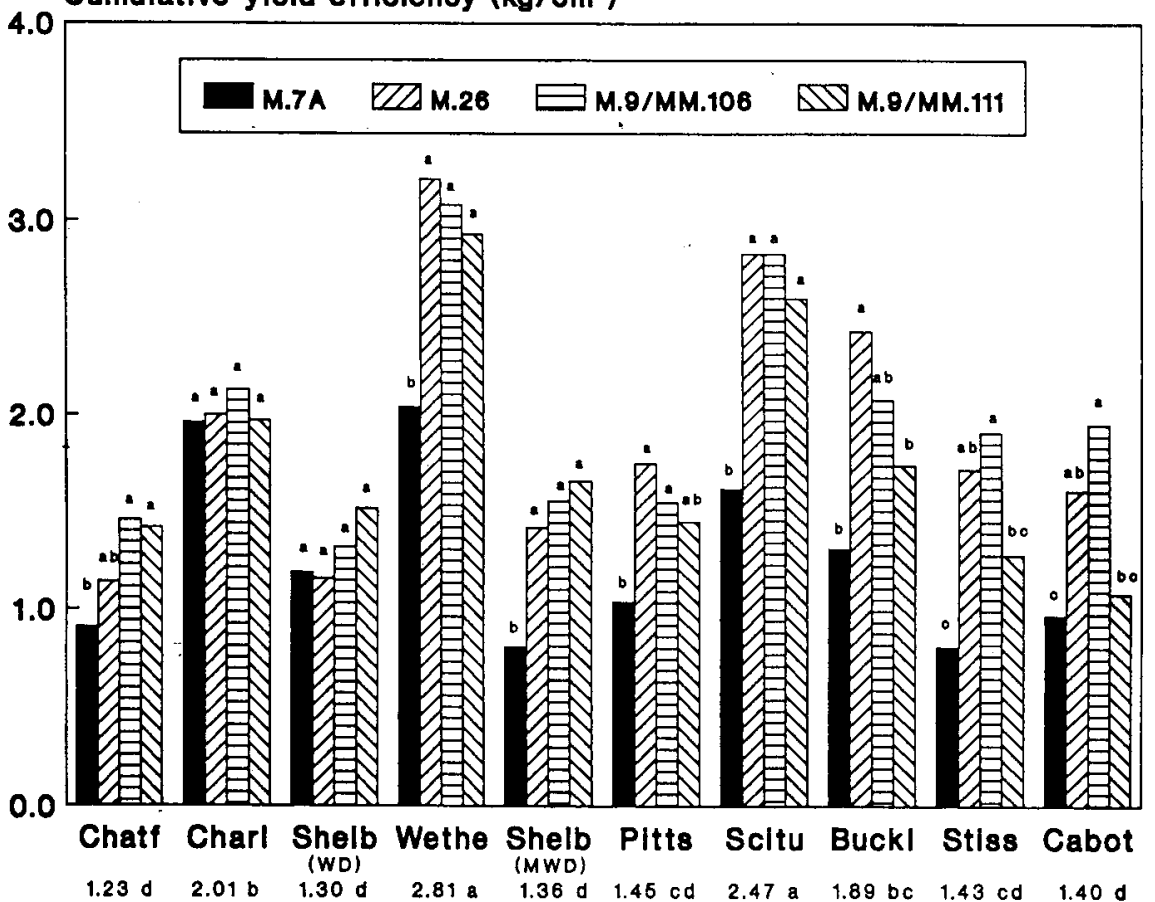

Fig. 2. Cumulative yield efficiencies (1986-88) of 'Marshall McIntosh' trees on M.7A, M.26, M.9/ MM.106, and M.9/MM.111 planted in 1982. Each bar represents the mean of eight observations, except where trees died. Within location, mean separation was by Duncan's new multiple range test, $P=0.05$. Location means (means of 32 observations, except where trees died) appear below the $\mathrm{x}$ axis labels and are separated by Duncan's new multiple range test, $P=0.05$. WD $=$ well-drained soil; MWD = moderately well-drained soil

within each location. Means were separated with Duncan's new multiple range test $(P=$ 0.05). All values presented are least-squares means.

Soil characteristics at each location are summarized in Table 1. Depth to seasonal high water table, as indicated by low chroma colors, was reflected in the soil drainage class. The Cabot soil had seasonal high ground- water at $26 \mathrm{~cm}$, indicating that the entire soil probably was saturated for a significant time during the growing season; the Charlton, Chatfield, Shelburne, and Wethersfield series did not have high seasonal groundwater within the soil profile. Presence of hardpan and bedrock within $90 \mathrm{~cm}$ also may have affected tree growth. Only in the Charlton series was the subsoil not restrictive to root penetration. In the Chatfield series, the presence of coarse sand within $49 \mathrm{~cm}$ and 'bedrock at $66 \mathrm{~cm}$ likely restricted root development; this effect partly was negated by the presence of a $21-\mathrm{cm}$-thick plow layer.

The effects of site and rootstock on tree size were significant (Table 2). The largest trees were on the Shelburne soil (well-drained, WD), and the smallest were on the Chatfield soil. The interaction between site and rootstock was nonsignificant, indicating that the relative differences among trees on the various rootstock were similar regardless of site. Trunk cross-sectional area of trees on M.7A was larger than that of the other rootstock, which were similar in this respect. Effects of site and rootstock on tree height and spread were similar to those on trunk cross-sectional area (Table 2).

The effects of site, rootstock, and the interaction of site and rootstock significantly affected cumulative yields for 1986-88 (Fig. 1). Trees on Chatfield, Buckland, Stissing, and Cabot soils produced the lowest yields. On the Chatfield, Charlton, Shelburne, and Wethersfield soils, trees on M.7A yielded more than trees on the other rootstock, although the differences were not statistically significant on the Chatfield soil. On none of the other sites did trees on M.7A yield significantly more than trees on the other rootstock. In fact, on the Shelburne (moderately well-drained, MWD) and the Stissing soils, trees on M.7A yielded significantly less than trees on M.26.

The cumulative (198688) yield efficiencies, as with cumulative yields, were significantly affected by soil, rootstock, and the interaction of soil and rootstock (Fig. 2). Trees on the Wethersfield and Scituate soils were significantly more yield-efficient than those on the Chatfield, Shelburne, Pittstown, Stissing, and Cabot soils. Trees on M.7A 
Table 2. Trunk cross-sectional area, height, and spread (Oct. 1988) of 'Marshall McIntosh' trees on M.7A, M.26, M.9/MM.106, M.9/MM.111 planted at 10 soil locations ${ }^{2 y}$.

\begin{tabular}{|c|c|c|c|}
\hline Variable & $\begin{array}{l}\text { Trunk cross- } \\
\text { sectional area } \\
\left(\mathrm{cm}^{2}\right)\end{array}$ & $\begin{array}{c}\text { Tree } \\
\text { ht } \\
(\mathrm{m})\end{array}$ & $\begin{array}{l}\text { Tree } \\
\text { spread } \\
(\mathrm{m})\end{array}$ \\
\hline \multicolumn{4}{|l|}{ Location } \\
\hline Chatfield & $18.4 \mathrm{f}$ & $2.1 \mathrm{f}$ & $2.0 \mathrm{e}$ \\
\hline Charlton & $39.3 \mathrm{e}$ & $3.1 \mathrm{de}$ & $3.1 \mathrm{bc}$ \\
\hline Shelburne (WD) ${ }^{x}$ & $80.8 \mathrm{a}$ & $3.7 \mathrm{a}$ & $3.7 \mathrm{a}$ \\
\hline Wethersfield & $42.1 \mathrm{de}$ & $2.8 \mathrm{e}$ & $3.1 \mathrm{bc}$ \\
\hline Shelburne (MWD) $)^{x}$ & $57.9 \mathrm{bc}$ & $3.5 a b c$ & $3.4 \mathrm{ab}$ \\
\hline Pittstown & $68.3 \mathrm{~b}$ & $3.5 \mathrm{ab}$ & $3.5 \mathrm{ab}$ \\
\hline Scituate & $52.7 \mathrm{~cd}$ & $3.4 \mathrm{bc}$ & $3.8 \mathrm{a}$ \\
\hline Buckland & $36.1 \mathrm{e}$ & $3.0 \mathrm{de}$ & $2.7 \mathrm{~d}$ \\
\hline Stissing & $48.4 \mathrm{cde}$ & $3.2 \mathrm{~cd}$ & $3.2 \mathrm{~b}$ \\
\hline Cabot & $35.2 \mathrm{e}$ & $2.8 \mathrm{e}$ & $2.7 \mathrm{~cd}$ \\
\hline \multicolumn{4}{|l|}{ Rootstock } \\
\hline M.7A & $71.1 \mathrm{a}$ & $3.6 \mathrm{a}$ & $3.5 \mathrm{a}$ \\
\hline M.26 & $43.8 \mathrm{~b}$ & $3.0 \mathrm{~b}$ & $3.1 \mathrm{~b}$ \\
\hline M.9/MM.106 & $38.7 \mathrm{~b}$ & $3.0 \mathrm{~b}$ & “3.0 b \\
\hline M.9/MM.111 & $38.2 \mathrm{~b}$ & $3.0 \mathrm{~b}$ & $2.9 \mathrm{~b}$ \\
\hline
\end{tabular}

${ }^{2}$ Each location mean is the mean of 32 observations, except for locations where trees died. Each rootstock mean is the mean of 80 observations, except for those treatments where trees died.

"Mean separation within each column and either location or rootstock by Duncan's new multiple range test, $P=0.05$.

${ }^{x} \mathrm{WD}=$ well-drained soil; MWD = moderately well-drained soil

and M. 26 were similarly yield-efficient on the Chatfield, Charlton, and Shelburne (welldrained) soils; however, at all other sites M.7A produced the least efficient trees. Trees on M.26 and M.9/MM. 106 were similarly yield-efficient at all sites. -The two interstem combinations were statistically similar, except on the Stissing and Cabot soils, where the efficiency of M.9/MM. 111 trees was significantly lower than that of M.9/MM. 106 trees.

This study shows that rootstock result in similar effects on tree vigor regardless of site, as has been shown by others (Parry, 1977; Rogers, 1946). There were clear differences, however, in the effects of rootstock on yield and yield efficiency among sites. These differences may have been due to the effects of soil conditions. Factors such as soil moisture, bulk density, macropore space, hydraulic conductivity, water holding capacity, and depth of the A horizon may interact with rootstock to affect tree performance. In this study, soil moisture may be used to explain some of the results; however, it must be recognized that soil moisture was not measured directly during this study. Instead, soil properties were assessed that reflect the average. moisture status. Two such measures-the average depth to seasonal high water table and the drainage class-were determined from the soil profile at the initiation of the study. During the term of the study, actual moisture levels may have varied from these estimates.

If the depth to seasonal high water table and drainage class were reasonable estimates of the soil moisture available during the study, the trends in tree performance, as measured by yield efficiency, were relatively clear. There was no particular advantage of using M.7A or M.9/MM.111 on the sites with the greatest potential for moisture deficiency, but these two rootstock often are recommended for dry locations over M.26 and MM.106 (Veneman, 1985). Because of their sensitivity to Phytophthora, M.26 and MM. 106 (in the M.9/MM. 106 interstem tree) often have been avoided on wet sites (Cummins and Norton, 1974); however, our results showed them to be the most efficient trees on sites with the potential for excess soil moisture. The seeming lack of sensitivity of M.9/
MM.106 to the wetter sites may be due to the burying of the MM. 106 root piece completely below the surface. Only the less Phytophthora -sensitive M.9 interstem was exposed at the ground line where Phytophthora is known to attack. Long-term longevity will have to be monitored to determine if M.26 andM.9/MM.106 are practical combinations for the sites with a potential for excess soil moisture.

In this study, M.26 and M.9/MM.106 performed well across all sites, suggesting a wider than expected adaptability. M.7A was the least desirable rootstock in this study, because it was the least efficient tree on all but two sites.

\section{Literature Cited}

Carlson, R.F. 1967. Growth response of several rootstock to soil water. HortScience 2:108-110

Cummins, J.N. and R.L. Norton. 1974. Apple rootstock problems and potentials. N.Y. State Agr. Expt. Sta. Food and Life Sci. Bul. 41.

Harris, R.V. and H.L. Pearse. 1938. The crown gall disease of nursery stocks. H. A progress report on experiments from 1929 to 1937 to determine the relative susceptibility of Mailing apple stocks and including the production of galls by synthetic growth substances. Annu. Rpt. E. Mailing Res. Sta. for 1937:188-193.

Harvey, W.R. 1979. Least-squares analysis of data with unequal subclass numbers. U.S. Dept. Agr.Agr. Res. Serv. Bul. H-4.

Harvey, W.R. 1985. User's guide for LSMLMW. Ohio State Univ., Columbus.

Makariev, Z. 1977. Response of apple to excessive soil moisture and resistance of rootstock to asphyxia. Ovoshcharstro 56(6):30-31.

Parry, M.S. 1977. Field comparisons of M.26 and other dwarfing apple rootstock on a diversity of sites. J. Hort. Sci. 52:59-73.

Rogers, W.S. 1946. Growth and cropping of apple trees on Mailing rootstock on five soil series. J. Pomol. 22209-226.

Rem, R.C. and S.A. Brown. 1979. Water tolerance of apples on clonal rootstock and peaches on seedling rootstock. Compact Fruit Tree 12:30-33.

Soil Survey Staff. 1972. Methods for analysis and collecting soil samples. U.S. Dept. Agr. Soil Conservation Serv., Washington, D.C.

Veneman, P.L.M. 1985. Compatibility of selected apple rootstock with Massachusetts soils. Fruit Notes 50(3): 1-4. 